\title{
Factors Influencing the Successful Adoption of Decision Support Systems: The Context of Aqaba Special Economic Zone Authority
}

\author{
Fairouz Mosleh Aldhmour (Assistant Professor) \\ Department of Management information Systems, Muta'h University \\ Karak, Jordan \\ Tel: 962-799-994-240Ｅ-mail: Firouzdomour@yahoo.com \\ Malek Bakhit Eleyan \\ Aqaba, Jordan \\ Tel: 962-799-199-945Ｅ-mail: malek.mba@hotmail.com \\ Received: August 20, 2011 \\ Accepted: October 8, 2011 \\ Published: January 16, 2012 \\ doi:10.5539/ijbm.v7n2p163 \\ URL: http://dx.doi.org/10.5539/ijbm.v7n2p163
}

\begin{abstract}
This research aimed to examine the main factors that influence the successful adoption of Decision Support Systems (DSS) in the Aqaba Special Economic Zone Authority (ASEZA). It investigated a set of factors which are; System Characteristics (Perceived Ease of Use (PEOU) \& Perceived usefulness (PU)), Technical Aspects (information technology infrastructure \& information systems interoperability), and Organizational Aspects (top management support (TMS), management style (MS), \& organizational structure (OS)).

A questionnaire was distributed to a sample of (161) respondents to collect primary data, \& based on a convenience sample the response rate was about $79 \%$. Furthermore, the findings were analyzed using the Statistical Package for Social Software (SPSS), with an R2 of 35.3\%, linear Multiple Regression analysis revealed that all research variables have significant effect on successful adoption of DSS.

The results indicated that PU \& IT infrastructures have a positive \& significant influence on the successful adoption of DSS. Whereas, PEOU, IS interoperability, TMS, MS, \& OS have no significant influence on the successful adoption of DSS. Finally, the findings indicated that no significant statistical differences existed between respondents' perceptions towards DSS adoption in terms of their demographic characteristics. Based on the research findings \& conclusions, a number of recommendations \& future research suggestions are proposed.
\end{abstract}

Keywords: Decision Support Systems, System characteristics, Technical aspects \& Organizational aspects

\section{Theoretical Background}

The rapid changes in the business environment can push the need for technologies \& their acceptance at an accelerating rate; organizations are becoming more flexible using various Information Systems (IS) to support more strategic \& complex decisions in order to achieve competitive advantage. Information Technology (IT) is a facilitator of organizational activities \& processes, \& is also an assistive tool. It has been used to support managers in decisions which were developed depending on intuition \& judgment of the decision makers. Many types of Computer-Based Information Systems (CBIS) have been developed to support decision making, including Decision Support Systems (DSS) (Nakmuang, 2004; Martin, Brown, Dehayes, Hoffer \& Perkins, 2002; Turban, Rainer \& Potter, 2001).

The first DSS were adopted by organizations around the world as far back as four decades ago. DSS can be described as "CBIS that help decision-makers to confront strategic problems through direct interaction with data \& analysis models" (Mcnurlin \& Sprague, 2004). DSS are designed to increase productivity, reduce cost, save time, increase the quality of decisions, achieve competitive edge, \& attain the effectiveness \& efficiency of the overall performance (Nokhbatol, Menhaj \& Shafiee 2010; Turban, Aronson, Liang, \& Sharda, 2007).

Therefore, the main aim of this research is to investigate a set of factors influencing the successful adoption of DSS within the context of Aqaba Special Economic Zone Authority (ASEZA). These factors are: First, the system characteristics (Perceived Ease of Use (PEOU), Perceived Usefulness (PU)). Second, technical aspects (IT 
Infrastructure, IS Interoperability). Finally, organizational aspects (Top Management Support (TMS), Management Style (MS), \& Organization Structure (OS).

\subsection{Adoption of DSS}

Many organizations continue to invest large amounts of resources in new IT, \& determining the potential acceptance of these new technologies is important (Chau, 1996). If the new IT is accepted \& adopted by users, the chances of the system \& investments` success greatly increase (Behrens et al, 2005).

Rogers (1995) defined the adoption as: "A decision to make full use of an innovation as the best course of action, whereas rejection is a decision not to adopt an available innovation".

Adoption is applied through a process which concerns a sequence of stages that a potential adopter of an innovation passes through before acceptance of a new system. Rogers (1995: p.21) defines the adoption process as:

"The process through which an individual or other decision-making unit passes from first knowledge of an innovation, forming an attitude towards the innovation, to a decision to adopt or reject the implementation of the new idea, \& to confirm this decision".

Premkumar \& Roberts (1999) agreed with Rogers (1995) as they considered five phases in the adoption process: Awareness stage of acquiring information about the innovation, persuasion stage of being persuaded to adopt the innovation, decision stage of deciding to adopt, implementation stage of implementing the innovation \& using it \& finally confirmation stage of evaluating the actual outcomes with expectations, these were clarifie in the Figure (1) (Innovation Diffusion Theory).

Many studies examined the acceptance \& the adoption of DSS like (Hart \& Jaques, 2005; Hart \& Porter, 2004; \& Hart et al, 2002). The need for businesses to adopt new system is the anticipated benefits from this system that would be brought to the organization. If users are not willing to accept the IS, it will not provide full benefits to the organization (Davis \& Venkatesh, 1996). In this research, it is proposed that there are several factors influencing the successful adoption of DSS for ASEZA.

In light of what mentioned above, the researcher defines the adoption of DSS process as:

"The process of knowing DSS (Awareness stage) \& being convinced to DSS (Persuasion stage), deciding to adopt DSS (Decision stage), applying its work standards \& regulations (Implementation stage), \& the willingness to invest in the IT infrastructure for better decisions of ASEZA \& the anticipated benefits from it (Confirmation).

Based on Rogers (1995), the researcher concluded that the context of ASEZA has passed the first three stages of (Awareness, Persuasion, \& Decision). Since the research is interested in the investigation of DSS adoption, two main system characteristics derived from the TAM Model are used as independent variables which are the PEOU $\&$ PU which affect the adoption of DSS; this Model (TAM) will be discussed in the next section.

Innovation Diffusion Theory (IDT) also presumes five innovation characteristics that affect the diffusion: relative advantage, compatibility, complexity, trialability \& observability (Rogers, 1995).

\subsection{System Characteristics}

Technology Acceptance Model (TAM) was developed by Davis et al, in 1989 as Figure (2) it explained the acceptance of IT in performing tasks \& identified two fundamental beliefs that influence the usage of an IS: PU \& PEOU.

\subsubsection{Perceived Usefulness (PU)}

TAM posits that PU is a significant factor affecting acceptance of an IS (Saeed \& Helm, 2008). Davis defined PU as "the degree to which a person believes that using a particular system would enhance his or her job performance" (Davis, 1989). It relates to job effectiveness, productivity (time saving) \& the relative importance of the system to one's job.

\subsubsection{Perceived Ease of Use (PEOU)}

Shen \& Chiou (2010) examined the impact of PEOU on Internet service adoption based on the original research by (Davis, 1989) regarding the PEOU of TAM. According to TAM, PEOU is a major factor that affects acceptance of IS. PEOU is defined as "the degree to which a person believes that using a particular system would be free of effort" (Davis, 1989)" in terms of physical \& mental effort as well as ease of learning (Davis, 1989). A specific application system is perceived to be useful by prospective users if they believe the system will improve or facilitate their job performance within the organizational context. The system is perceived to be easy to use if the prospective user believes that the use of the system will be free of effort (Davis, 1993).

As TAM proposes, both PU \& PEOU are important in technology acceptance \& usage. However, their relative importance in the acceptance process has been shown to be different in previous studies. For instance, Davis (1993) 
found that PU dominated PEOU, whereas Adams et al, (1992) found PEOU to be more influential than PU, Which Chan (2009) concluded as the DSS use increased when PEOU \& PU of the DSS are high.

PU \& PEOU may be influenced by various external variables, possibly user`s features such as level of education, gender (Venkatesh \& Morris, 2000). It has been found that all external variables influence the intention to use the IT system (Yarbrough \& Smith, 2007; Lee et al, 2006).

Accordingly, the user's beliefs of usefulness not only have direct influence on their intention toward adopting IT, but have indirect influence on intention via attitude. Finally, the users' PU is influenced by his or her PEOU (Davis, 1993).

In this research, the researcher examined the impact of PU \& PEOU on DSS adoption \& compatible with Rigopoulos et al, (2008) who found that PEOU \& PU support the adoption of DSS.

\subsection{Technical Aspects}

In this section the researcher introduced the main technical aspects that impact adopting DSS: IT infrastructure \& IS interoperability.

\subsubsection{Information Technology Infrastructure}

The main component of the IT investment, the development of an effective IT infrastructure is placed among the top concerns of overall IT management. Organizations spend a considerable amount of money \& time to build IT infrastructure. However, a large number of companies have not achieved their expected returns from their IT investment; they seem to plunge into "IT black hole". The critical reason is that these companies have not effectively combined IT infrastructure with their business resources to form "IT capability" (Xianfeng, 2008).

An IT infrastructure is a concept that means different things to different organizations at different times. Organizations today can choose from thousands of components to build their IT infrastructure from individual software to strategic functions. An IT infrastructure includes the hardware, software, \& telecommunications equipment that, when combined, provide the underlying foundation to support the organization's goals (Haag et al, 2005).

Laudon \& Laudon, (2010: p.191) indicated that IT infrastructure consists of a set of physical devices \& software applications that are required to operate in the entire enterprise. But IT infrastructure is also a set of organization wide service budgeted by management $\&$ comprising both human $\&$ technical capabilities.

The organization's IT infrastructure basically integrates technology components to support business needs. The definition of IT infrastructure encompasses a variety of components, based on previous studies, Byrd \& Turner (2000: p.172) provided a thorough definition of IT infrastructure as:

"The shared IT resources consisting of a technical physical base of hardware, software, communications technologies, data, \& core applications \& a human component of skills, expertise, competencies, commitments, values, norms, \& knowledge that combine to create IT services that are typically unique to an organization. These IT services provide a foundation for communications interchange across the entire organization \& for the development \& implementation of present \& future business applications".

\subsubsection{Information Systems Interoperability}

In a broad sense, IS interoperability refers to the use of computer-based tools that facilitate coordination of work \& information flow across organizational boundaries, focusing mainly on inter-enterprise distributed business processes \& flows. It emerged mainly from the need to harmonize the operational heterogeneous networked environment, real information sharing, \& the necessity to improve task coordination (Chituc et al, 2008).

According to (Ram, 1991), IS interoperability represents the capability of two or more systems or components to exchange information, \& to use it. While Stegwee \& Rukanova (2003) extend this technical definition to an organizational context \& suggest that IS interoperability resides at the interplay of human systems, business processes, \& enabling technologies. Prior studies have explored IS interoperability issues in a wide variety of domains, including heterogeneous databases, information retrieval, knowledge systems, artificial intelligence, multimedia, GIS, interoperable system architecture design, \& business process modeling. Ionescu et al, (2009) focused on consolidation of the financial data through the interoperability of the financial \& accounting applications in the companies.

\subsection{Organizational Aspects}

Based on an extensive review of the available literature, it is revealed that a number of organizational factors can influence adoption of DSS. Ngai et al, (2008) found that TMS is critical factor to the successful implementation of IS. Also, identified organizational variables as TMS, MS, department structure, size of IS function, evaluator perspective, culture, \& IS budget size by (Rezaei et al, 2009; Hussein et al, 2007; Lu \& Wang, 1997; Saunders \& 
Jones, 1992). Shaukat \& Zafar (2010) found that OS impact on the implementation of IT. Ang et al, (2001) identified organizational factors that influence IT usage as OS, TMS, organizational size, managerial IT knowledge, financial resources, goal alignment $\&$ budgeting method.

In the next section \& based on a comprehensive list of organizational factors from related studies (Shaukat \& Zafar, 2010; Ngai et al, 2008; Elbeltagi et al, 2005; Ang et al, 2001; \& Tallon et al, 2000), the researcher will discuss three organizational factors that influence successful DSS adoption in this research. The three factors are TMS, MS \& OS.

\subsubsection{Top Management Support (TMS)}

TMS has been identified as a key predictor in the adoption \& implementation of IT (Fink, 1998). Several previous studies have shown that TMS is a significant predictor of technology adoption \& leads to more successful IT use in many organizations (Seyal \& Rahman, 2003; Caldeira \& Ward, 2002; Tang \& Teo, 2000). It is important to create a supportive climate \& adequate resources for the adoption of new technology (Premkumar \& Roberts, 1999). In addition, Elbeltagi et al, (2005) indicated that TMS is as an important factor of DSS usage success.

However, without the support from top management, it will result in stronger resistance from employees \& will become a substantial barrier to the adoption of data warehouse (Haley, 1997). Therefore, it is expected that the greater the extent of TMS, the more likely the organization will adopt DSS.

\subsubsection{Management Style (MS)}

MS is a key requirement for successful implementation of any system (Rezaei et al, 2009; \& Hussein et al, 2007). MS deals with the way in which the management tends to influence, coordinate, $\&$ direct people's activities towards group's objectives (Robbins, 1994; Aldag \& Stearns, 1991). Lu \& Wang (1997) pointed out that many studies have categorized MS into people-oriented \& task-oriented tasks. People-oriented managers consider inter-personal relationship \& are concerned with mutual trust, friendship, respect \& warmth. On the other h\&, task-oriented managers tend to focus more on task aspect of jobs \& deals with defining \& organizing tasks for goal attainment.

Lu \& Wang (1997) investigated the relationship between MS with user participation \& systems success over MIS growth stages. The researchers found mixed results. They found that MS were related to system success differently over the MIS growth stages. For example, at the development stage \& the maturity stage, both people-oriented \& task-oriented styles had positive significant relationship with system success. On the other hand, at the initiation stage, both styles have no effect on system success. They argued that at the initiation stage, computer is being introduced to the organization \& users must learn the new technology on their own. This, in turn ended up into dissatisfaction among the users.

However, the authors agreed that more issues need to be explored involving the many styles of management. Based on the above discussion, the researcher believes that MS may influence DSS adoption.

\subsubsection{Organizational Structure (OS)}

Shaukat \& Zafar (2010) said that OS is an important factor to be considered in technology adoption. Similarly interaction among members at all levels among all departments \& teams is also necessary for successful introduction of new technology. Also Liu \& Hu (2007) found that OS has an effect on technological innovation.

Vroom (2002: p.54) defined OS as "the way in which an organization is built up, the way in which relations \& relationships between people in an organization are more or less regulated". The OS needs to provide a frame to differentiate the organizations or units main task \& to allocate derived subtasks to different workers. Subsequently these subtasks need to be reintegrated to achieve the overall goal (Mintzberg, 1983).

According to Stair \& Reynolds (2010), OS refers to organizational sub-units \& the way they relate to the overall organization. An OS can affect how IS are viewed \& used. Although there are many possibilities.

So, the researcher sees that OS is an important factor to be considered in DSS adoption. Similarly interaction among members at all levels among all departments \& teams is also necessary for successful DSS adoption.

\section{Previous Studies}

DSS has a significant effect on the subjects' ability to recognize problems, generate \& evaluate alternatives, \& choose final alternative; rating the system as effective in decision-making according to Forgionne \& Kohli, (2000). While Chen \& lee, (2003), emphasized about the need to support the decision maker's general thinking processes to reduce cognitive biases in decision making \& provide some initial evidence that the system could be a valuable cognitive support tool after further development. Kohli \& Devaraj, (2004) also provided evidence that DSS usage leads to improvements in organizational performance. Forgionne \& Newman, (2007) who found that creativity-enhanced concept is superior to traditional DSS approaches in guiding the decision-maker towards an 
effective policy or strategy. In addition, Cowie \& Burstei, (2007) also addressed the issue of quality of data that was considered as an important factor influencing the quality of the decision by implement of the DSS. A summary of some of the previous studies" factors affecting the adoption of DSS" are listed in the next table (Table 1).

\section{Problem Statement}

The problem of this research stems from detecting the factors that influence the successful adoption of DSS in the context of ASEZA, as there are many factors emphasizing the need to adopt DSS; such as technological development, competition $\&$ the desire to improve the work. This research attempts to answer the following main question: "What are the main factors that influence the successful adoption of DSS in ASEZA"?

\section{Research Aim and Objectives}

The main aim of this research is to investigate the factors influencing the successful adoption of DSS within the context of ASEZA. To achieve this aim, the following objectives were proposed:

- To examine the impact of system characteristics on the successful adoption of DSS in the context.

- To examine the impact of technical aspects on the successful adoption of DSS in the context.

- To examine the impact of organizational aspects on the successful adoption of DSS in the context.

- To investigate whether there are differences in the respondent's perceptions toward adoption of DSS based on the demographic characteristics of ASEZA's managers (gender, age, commission, job description, education level, \& experience).

\section{Research Model}

To study the main factors influencing successful adoption of DSS, the researcher relies on previous studies, the TAM model \& his observations in building the proposed model below.

\section{Research Importance}

The importance of this research can be derived from the following:

- The lack of studies that focus on DSS in the Arab country, \& particularly in Jordan. Therefore, this research may represent a starting point for further research to cover other factors affecting DSS adoption (which are not discussed in this research).

- The magnitude of this research is obtained from the value of DSS which represents the ultimate investment of IT for ASEZA, which is considered one of the biggest private public integration entities in the area, due to its high costs, yet being considered as a new strategic technological \& organizational tool in this empirical research of ASEZA.

- The findings of this research will be useful not only for academics \& business people, but also for ASEZA \& any other organization's managers \& decision makers.

- This research is considered a pioneer study investigating a new \& very important factor; the IS interoperability on DSS' successful adoption.

\section{Design and Methodology}

The researcher uses a deductive approach which is more likely to work with quantitative data in order to answer the questions about relationships among measured variables with the purpose of explaining, predicting \& controlling phenomena. Thus, the aim of a deductive approach is to generalize from a sample to a population (Leedy \& Ormrod, 2001).

The design was quantitative because the data took a numerical form. That is, by employing a deductive approach with a quantitative research method, the researcher has been able to measure $\&$ analyze the relationship between influencing factors \& the successful adoption of DSS. This approach also allows for testing the research hypotheses \& generalizing the research findings to the population (Zikmund, 2003).

The methodological approach in this research is a descriptive one, because the researcher attempts to identify, explain variables of this research $\&$ to describe the relationships between these variables in order to provide a picture of a particular phenomenon, but not to ferret out cause-effect relationships (Churchill \& Iacobucci, 2002).

According to Yin (1994) there is one main reason for using the survey strategy, which other strategies cannot provide. For example, a number of the research questions in this study are related to who, what, when, where, how many or how much, \& to what extent. These are appropriate for surveys, while the question type using how $\&$ why are suitable for a case study (Yin, 1994). The nature of questions in this research being investigated, for instance is "What are the main factors that influence the successful adoption of DSS in ASEZA"? \& according to the previous study it is appropriate to use a survey-based research approach. 
The procedure of selecting (204) managers (Top \& Middle levels ) in ASEZA was based on the convenience sampling method, as it is considered the best way of getting some basic information quickly \& efficiently (Sekaran, 2006). In addition, the researcher considered this procedure for its compatibility with the distinctiveness of DSS for the managers. The researcher distributed (204) questionnaires, (161) questionnaires were returned \& were valid for analysis; these questionnaires were distributed to all of ASEZA's top \& middle management managers.

\section{Data Analysis}

Construct validity has been assessed by using correlation analysis, the result of testing the validity showed in Table (2). It implies that items that are indicators of a specific construct should converge or share a high proportion of variance (Hair et al, 2006). In other words, it assesses the degree to which measures of the same concept are correlated, with high correlation indicating that the scale is measuring its intended concept.

The item-to-total correlations in this research all exceed (0.5) \& all items were significant because $(\mathrm{Sig}=.000<0.01)$; with each dimension demonstrating properties of good validity, the fitness of these models can now be assessed.

The reliability of the scales was established by utilizing Cronbach's alpha (Table 3). Considering the present research as a whole, Cronbach's alpha varied from (0.64-0.89), which is considered acceptable for this type of research.

To analyze Multi-collinearity, two types of measurements can be used: Variation Inflation Factor (VIF) \& Tolerance. The VIF, measures the extent the variance of the estimated regression coefficients are inflated as a result of being related to the other independent variables, \& Tolerance is the amount of variability of the selected independent variables not explained by other independent variables.

Results in Table below (4) shows that VIF for all independent variables ranged between (1.109 - 2.063), which are less than the limited valued (10) \& Tolerance for all independent variables ranged between $(.485-.901)$, which are greater than $(0.10)$. This indicates that there was no high correlation among the independent variables (Multi-collinearity).

The ratio of Skewness to its standard error can be used as a test of normality (that is, you can reject normality if the ratio is less than -2 or greater than +2 ). A large positive value for Skewness indicates a long right tail; an extreme negative value indicates a long left tail" (SPSS Base 16.0 users Guide, 2007: p.276). Table (5) presents the Skewness normality distribution test:

The reading of the Skewness test findings, all variables are normally distributed, ranging from (-1.353 to -.122) falling within the interval of $(2,-2)$.

Fitness of the Model: the linear regression analysis of the original model reveals that the R-square of the model is 0.352 . This means that the model explains $35.2 \%$ of the variance in the dependent variable as shown in Table (6) below. The model is statistically significant, as the p-value for the model is 0.000 which is less than the limit for statistical significance limit in same Table, which is 0.10 for weak significance \& 0.05 for significance. This level is good; meaning that the fitness of the model in explaining the adoption process is high.

From the results showed in Table (7), PEOU has a non-significant direct effect on successful adoption of DSS in ASEZA $(\mathrm{t}=1.049 ; \mathrm{sig}=.296)$. While PU has a significant direct impact on the successful adoption of DSS in ASEZA $(\mathrm{t}=3.709 ; \mathrm{sig}=.000)$. Furthermore, IT infrastructure has

a significant direct impact on the successful adoption of DSS in ASEZA $(t=5.039$; $\mathrm{sig}=0.000)$.

IS interoperability has no significant direct impact on the successful adoption of DSS in ASEZA $(t=.143$; sig $=.886)$. TMS has a non-significant direct effect on the successful adoption of DSS in ASEZA $(\mathrm{t}=-.411$; sig $=.682$ ).

In addition, the results indicated that MS has a non-significant direct effect on the successful adoption of DSS in ASEZA $(\mathrm{t}=-.022-; \mathrm{sig}=.983)$. OS has a non-significant direct effect on the successful adoption of DSS in ASEZA $(\mathrm{t}=.889 ; \mathrm{sig}=.376)$.

Based on the results shown in Table (8), T-test analysis (Independent Sample t-test) was used to test if there is no significant statistical difference between respondent's perceptions towards adoption of DSS according to the gender. Result showed a ( $\mathrm{f}=2.035 ; \mathrm{Sig}=.156)$ for gender.

Table (9), ANOVA was used to test if there is no significant statistical difference between respondents perceptions towards the adoption of DSS according to the Age, Education level, commission, Job description, \& Experience (see Table 9). Results showed a ( $\mathrm{f}=1.631 ; \mathrm{sig}=.089)$ for age, has $(\mathrm{f}=.551 ; \mathrm{sig}=.878)$ for Education level, has (f $=1.241 ; \mathrm{sig}=.260)$ for Commission, has $(\mathrm{f}=.754 ; \mathrm{sig}=.696)$ for Job description, \& has $(\mathrm{f}=1.431 ; \mathrm{sig}=.158)$ for Experience. Thus, (H04) was accepted. \& therefore, it was found that there is no significant statistical difference 
between respondent's perceptions towards DSS adoption in terms of their (gender, Age, Education level commission, Job description, Experience).

\section{Discussion}

The research findings indicated that managers in ASEZA appear to make their successful DSS adoption based on its PU \& IT infrastructure. These results are somewhat consistent with the findings of previous studies. In light of the research objectives \& the hypotheses testing the researcher has revealed the following overall conclusions:

\subsection{System Characteristics}

\subsubsection{Perceived Ease of Use}

The research accepted H01.1. This is due to the fact that ASEZA has not fully applied the DSS yet \& also the respondents see that the system's PEOU does not have any affect on the successful adoption of DSS. In contrast, Rigopoulos et al, (2008) found that PEOU have positive effects on DSS adoption. However, in this research, the researcher found that PEOU has no effect on the successful adoption of DSS within the context of ASEZA.

\subsubsection{Perceived Usefulness}

The researcher found that PU has a positive affect on the successful adoption of DSS in ASEZA, due to the respondents' awareness of DSS's importance as it will facilitate the managerial decision making process, hence H01.2 is rejected. These findings are similar to the results of many previous studies, such as the studies of (Chan, 2009; Rigopoulos et al, 2008; Elbeltagi et al, 2005).

\subsection{Technical Aspects}

\subsubsection{IT infrastructure}

Through examining the H02.1, the researcher found that IT infrastructure has a positive role in the successful adoption of DSS in the context of ASEZA, hence this H02.1 is rejected. The researcher believes that this result is the consequence of the orientation of ASEZA toward technology. ASEZA strives to build strong technical environment in order to operate a new system such as DSS. This finding is similar to the results arrived at by Benamati \& Lederer (2008) who found that successful DSS depend on an IT infrastructure that gathers, stores, \& provides appropriate information.

\subsubsection{IS Interoperability}

The researcher found that IS interoperability has no effect on the successful adoption of DSS in ASEZA hence H02.2 is accepted. The researcher believes that this result is due to the simple knowledge regarding the term Interoperability for the (non-technical departments respondents). On the other h\&, the IT department had a deep understanding of the term. Never the less, no effect was found due to the respondent's magnitude of the other departments over the IT department.

\subsection{Organizational Aspects}

\subsubsection{Top Management Support}

The researcher found that TMS has no effect on the successful adoption of DSS in ASEZA, hence H03.1 is accepted, \& this result is related to the respondents' personal opinions as individuals regarding ASEZA's top management policies. However, It is indicated severally in research literature that TMS is a key factor affecting the adoption of new IT \& has the greatest effect on DSS usage, it would also help the employees to overcome resistance \& facilitate acceptance of new IS applications adoption, implementation or utilization (Ngai et al, 2008; Hussein et al, 2007; Elbeltagi et al, 2005; Nathan et al, 2004; Ang et al, 2001).

\subsubsection{Management Style}

The researcher found that MS has no effect on the successful adoption of DSS in ASEZA, hence H03.2 is accepted. The researcher believes that the respondents see that MS has no affect on successful adoption of DSS regardless of style (People \& Task Oriented Styles). On the contrary, Rezaei et al, (2009) \& Hussein et al, (2007) found that MS has the highest predictor of IS success. People-oriented MS is more prevalent than task-oriented MS. This outcome is due to the state where users are more comfortable towards a people-oriented style \& managers giving emphasis on inter-personal relationships. This is partially supported by Lu \& Wang's (1997) research, which asserted the significance of people-oriented style in the earlier stages to system.

\subsubsection{Organizational Structure}

The researcher found that OS has no effect on the successful adoption of DSS in ASEZA, hence H03.3 is accepted, $\&$ this result can be justified by the respondents point of view that the heterogeneous OS of ASEZA contains different departments, sections \& teams with divergent responsibilities $\&$ authorities, $\&$ it is not properly aligned for implementation of a new technology. However, several studies have found that OS is necessary for the 
successful introduction of new technology adoption \& it is an important factor to be considered when implementing any technology (Shaukat \& Zafar, 2010; Liu \& Bei, 2007).

\subsection{Demographic Variables}

The researcher found no significant statistical differences in the respondents' perceptions toward DSS adoption that can be attributed to demographic characteristics within the context of ASEZA, hence H04 is accepted. This is attributed to the fact that all respondents are motivated towards any new technology, such as DSS, that would help with their job tasks, regardless of their demographic characteristics. This finding, however, isn't consistent with Liu \& Chen (2008) \& Masrek et al, (2007) who found individual differences toward the acceptance of DSS.

\section{Conclusions and Recommendations}

In light of the research objectives $\&$ empirical results, $\&$ in order to answer the research questions outlined at the beginning of this research, the researcher has reached the following as overall conclusions:

1) PU \& IT infrastructure has a positive effect on the successful adoption of DSS in the context of ASEZA.

2) The remaining factors (PEOU, IS interoperability, TMS, MS, OS, \& demographic characteristics) have no effect on the successful adoption of DSS in the context of ASEZA.

3) ASEZA has a very strong base of IT infrastructure that is capable of adopting DSS, but based on the respondents point of view; ASEZA's top Management does not have enough organizational transparency to clarify the long term (strategic) goals of adopting such systems leaving managers in confusion. ASEZA must maintain the actual level of orientation towards technology \& clarify the purposes of its adoption as a helping tool \& not a replacement for these managers. It should also keep a consistent rate of growth \& development for the IT infrastructure, because of its big importance as an investment for ASEZA \& its positive effect on the successful adoption of DSS in the context of ASEZA.

4) The researcher noticed that there is not enough communication between the top management \& the managerial departments \& therefore the respondents did not find any clear \& obvious role for the top management towards the adoption of DSS. ASEZA must pay more attention to the organizational aspects represented in TMS, MS, OS towards adopting \& DSS, \& would have to clarify the strategic purposes \& goals of using such systems through comprehensive \& continuous trainings \& workshops for the employees using this system (Top \& Middle Management Level Managers) rather than classifying such procedures as organizational secrecy issues based on the conclusion stating the lack of communication between top management $\&$ the managerial departments.

5) ASEZA's managers share a collective opinion regarding accepting DSS as a new system using new technologies, \& this is considered as a rare case especially in a big organization of ASEZA's scale \& with varied demographic characteristics.

\section{Research limitations}

This research has a number of limitations that should be taken into account when evaluating and generalizing its conclusions. However, the limitations discussed below can provide the starting point for future research:

1) In this research the researcher used a single method in data collection (questionnaires) to test a number of hypothesized relationships.

2) At the end of this research the researcher faced some difficulties in some departments due to the organizational change that ASEZA was and is still going through, especially in the delay of questionnaire's collection stage, as most of the managers were busy in meetings on constantly changing work policies because of the changes in the top management.

\section{References}

Adams, D., Nelson, R., \& Todd, P. (1992). Perceived Usefulness, Ease of Use \& Usage of Information. MIS Quarterly, Vol.16, N.2, pp.227-248. http://dx.doi.org/10.2307/249577

Aldag, R., \& Stearns, T. (1991). Management. Cincinnati, OH: South-Western Publishing Company.

Ana, R., Del, A., \& Antonio P. (2006). Organizational factors affecting Internet technology adoption. Internet Research, Vol. 16, N.1, pp.94-110. http://dx.doi.org/10.1108/10662240610642569

Ang, C., Davies, M., \& Finlay, P. (2001). An Empirical Model of IT usage in the Malaysian Public Sector. Journal of Strategic Information Systems, Vol.10, N.2, pp.159-174. http://dx.doi.org/10.1016/S0963-8687(01)00047-6

Bajwa, D., \& Ross, S. (2002). Factors influencing the adoption \& implementation of organizational intranets. Issues in Information Systems, Vol.3, N.7, pp. 28-34. 
Behrens, S., Jamieson, K., Jones, D., \& Cranston, M. (2005). "Predicting system success using the technology acceptance model: A case study". Paper presented to 16 th Australasian conference on information systems, Sydney, Australia.

Bradford, M., \& Florin, J. (2003). Examining the role of innovation diffusion factors on the implementation success of enterprise resource planning systems. International Journal of Accounting Information Systems, Vol.4, N.21, pp.205-225. http://dx.doi.org/10.1016/S1467-0895(03)00026-5

Byrd, T., \& Turner D. (2000). Measuring the flexibility of information technology infrastructure: Exploratory analysis of a construct. Journal of Management Information Systems, Vol.17, N.1, pp.167-208.

Caldeira, M., \& Ward, J. (2002). Understanding the successful adoption \& use of IS/IT in SMEs: an explanation from Portuguese manufacturing industries. Information Systems Journal, Vol.12, N.2, pp.121-152. http://dx.doi.org/10.1046/j.1365-2575.2002.00119.x

Chan, S. (2009). The roles of user motivation to perform a task \& decision support system (DSS) effectiveness \& efficiency in DSS use. Computers in Human Behavior, Vol.25, N.12, pp. 217-228. http://dx.doi.org/10.1016/j.chb.2008.09.002

Chau, P. (1996). Empirical assessment of a modified technology acceptance model. Journal of Management Information Systems, Vol.13, N.2, pp. 185-204.

Chen, J., \& Lee, S. (2003). An exploratory cognitive DSS for strategic decision making. Decision Support Systems, Vol. 14, N.14, pp. 147-160. http://dx.doi.org/10.1016/S0167-9236(02)00139-2

Chituc, C. Toscano, C., \& Azevedo, A. (2008). Interoperability in Collaborative Networks: Independent \& industry-specific initiatives-The case of the footwear industry. Computers in Industry, Vol. 59, N.7, pp.741-757. http://dx.doi.org/10.1016/j.compind.2007.12.012

Churchill, G., \& Iacobucci, D. (2002). Marketing research: Methodological foundations. (8th Ed.). Orl\&o: Harcourt College Publishers.

Cowie, J., \& Burstein, F. (2007). Quality of data model for supporting mobile decision making. Decision Support Systems, Vol.43, N.4, pp.1675-1683. http://dx.doi.org/10.1016/j.dss.2006.09.010

Davis, F. (1989). Perceived usefulness, perceived easy of use, \& user acceptance of information technology. MIS Quarterly, Vol.17, N.3, pp.319- 339. http://dx.doi.org/10.2307/249008

Davis, F. (1993). User Acceptance of Information Technology: Systems Characteristics, User Perceptions \& Behavioral Impacts. International Journal of Man-Machine Studies, Vol. 38, N.3, pp.475-487. http://dx.doi.org/10.1006/imms.1993.1022

Davis, F., \& Venkatesh, V. (1996). A critical assessment of potential measurement biases in the technology acceptance model: three experiments. International Journal of Human-Computer Studies, Vol.45, N.1, pp.19-45. http://dx.doi.org/10.1006/ijhc.1996.0040

Davis, F., Bagozzi, R., \& Warshaw, P. (1989). User acceptance of computer technology: a comparison of two theoretical models. Management Science, Vol.35, N.8, pp.982-1003. http://dx.doi.org/10.1287/mnsc.35.8.982

Elbeltagi, I., McBride, N., \& Hardaker, G. (2005). Evaluating the factors affecting DSS usage by senior managers in local authorities in Egypt. Journal of Global Information Management, Vol.13, N.2, pp.42-65. http://dx.doi.org/10.4018/jgim.2005040103

Fink, D. (1998). Guidelines for successful adoption of information technology in small \& medium enterprises. International Journal of Information Management, Vol.18, N.4, pp.243-53. http://dx.doi.org/10.1016/S0268-4012(98)00013-9

Forgionne, G., \& Kohli, R. (2000). Management support systems effectiveness: further empirical evidence. Journal of Association for Information Systems, Vol.1, N.3, pp.1-39.

Forgionne, G., \& Newman, J. (2007). An experiment on the effectiveness of creativity enhancing decision-making support systems. Decision Support Systems, Vol.42, N.11, pp.2126-2136. http://dx.doi.org/10.1016/j.dss.2006.05.009

Grandon, E., \& Pearson, J. (2004). Electronic commerce adoption: an empirical study of small \& medium US businesses. Information \& Management, Vol.42, pp.197-216. http://dx.doi.org/10.1016/j.im.2003.12.010

Haag, S., Cummings, M., \& Mccubbrey, D. (2005). Management Information Systems for the Information Age. McGraw-Hill/Irwin Companies, New York, NY.

Hair, J., Black, W., Babin, B., \&erson, R., \& Tatham, R. (2006). Multivariate Data Analysis. (6th Ed.). Pearson 
Education, Inc, Upper Saddle River, NJ.

Haley, B. (1997). Implementing the decision support infrastructure: Key success factors in data warehousing. Unpublished Ph.D. thesis, University of Georgia.

Hart M., Davies, K., Barker-Goldie, E., \& Theron, L. (2002). Issues Affecting the Adoption of Data Mining in South Africa. South African Computer Journal, Vol.29, pp.41-48.

Hart, M., \& Jaques, A. (2005). OLAP Technology in South Africa: Applying the Unified Theory of Acceptance \& Use of Technology (UTAUT). Research report, Department of Information Systems, University of Cape Town.

Hart, M., \& Porter, G. (2004). The Impact of Cognitive \& Other Factors on the Perceived Usefulness of OLAP. Journal of Computer Information Systems, Vol.45, N.1, pp.47-56.

Hussein R., Abdul Karim N., \& Selamat H. (2007). The impact of technological factors on information systems success in the electronic-government context. Business Process Management Journal, Vol. 13, N.5, pp.613-627. http://dx.doi.org/10.1108/14637150710823110

Hussein R., Abdul Karim N., Mohamed, N., \& Ahlan, A. (2007). The Influence of Organizational Factors on Information Systems Success in E-Government Agencies in Malaysia. The Electronic Journal of Information Systems in Developing Countries, Vol.29, N.1, pp.1-17. '

Hwang, H., Ku, C., David, C., \& Cheng, C. (2004). Critical factors influencing the adoption of data warehouse technology: a study of the banking industry in Taiwan. Decision Support Systems, Vol.37, N.1, pp.1-21. http://dx.doi.org/10.1016/S0167-9236(02)00191-4

Ionescu, I., Ionescu, B., Mihai, F., \& Cojocaru, S. (2009). Financial \& Accounting information systems interoperability. Annales Universitatis Apulensis Series Oeconomica, Vol.11, N.1, pp.335-344.

Kohli, R., \& Devaraj, S. (2004). Contribution of institutional DSS to organizational performance: evidence from a longitudinal study. Decision Support Systems, Vol.16, pp.103-118. http://dx.doi.org/10.1016/S0167-9236(02)00211-7

Laudon, K., \& Laudon, J. (2010). Management Information Systems, Management the Digital firm. (11th Ed.). Pearson Prentice Hall.

Lee, S., Kim, I., Rhee, S., \& Trimi, S. (2006). The role of exogenous factors in technology acceptance: The case of object-oriented technology. Information \& Management, Vol.43, pp.469-480. http://dx.doi.org/10.1016/j.im.2005.11.004

Leedy, P., \& Ormrod, J. (2001). Practical Research: Planning \& design. (7th Ed.). Pearson Educational International \& Prentice Hall: New Jersey.

Liu, Q-H, \& Hu., B. (2007). Organizational Structure \& Technological Innovation: An Empirical Study in Chinese Automobile Industry. Management Science \& Engineering, Harbin, pp.1115-1120.

Liu, Y., \& Chen, A. (2008). The Effect of Individual Differences, Tasks, \& Decision Models on User Acceptance of Decision Support Systems. Association for Information Systems, Proceedings of the Fourteenth Americas Conference on Information Systems, paper 357.

Lu, H., \& Wang, J. (1997). The Relationship between Management Styles, User Participation, \& System Success over MIS growth stages. Information \& Management, Vol.32, N.3, pp.203-213. http://dx.doi.org/10.1016/S0378-7206(97)00021-9

Martin, E., Brown. C., Dehayes, D., Hoffer, J., \& Perkins, W. (2002). Managing information technology Pearson Education. Inc., Upper Saddle River, New Jersey.

Mcnurlin, B., \& Sprague, R. (2004). Information Systems Management in Practice. (6th Ed.). Prentice Hall, Englewood Cliffs, NJ.

Mintzberg, H. (1983). Structure in Fives: Designing Effective Organizations. Prentice-Hall, New Jersey.

Nakmuang, T. (2004). Decision support systems. (18 March, 2007). [Online] Available: http://www.sirikitdam.egat.com/WEB_MIS/107/index.html

Nathan, B., Apigian, C., Nathan, T., \& Tu, Q. (2004). A path analytic study of the effect of top management support for information systems performance. Omega, Vol.32, N.6, pp. 459-471. http://dx.doi.org/10.1016/j.omega.2004.03.001

Ngai, E., Law, C., \& Wat, F. (2008). Examining the Critical Success Factors in the Adoption of Enterprise Resource Planning. Computers in Industry, Vol.59, N.6, pp.548-564. http://dx.doi.org/10.1016/j.compind.2007.12.001 
Nokhbatol, F., Menhaj, H., \& Shafiee, M. (2010). Fuzzy decision support system for crisis management with a new structure for decision making. Expert Systems with Applications journal, Vol.37, pp.3545-3552.

Premkumar, G., \& Roberts, M. (1999). Adoption of new information technologies in rural small businesses. International Journal of Management Science, Vol.27, N.4, pp.467-484.

Ram, S. (1991). Heterogeneous distributed database systems. Special Issue. IEEE Computer, Vol.24, N.12.

Rezaei, A., Asadi, A., Rezvanfar, A., \& Hassanshahi, H. (2009). The impact of organizational factors on management information system success: An investigation in the Iran's agricultural extension providers. The International Information \& Library Review, Vol.41, PP.163-172.

Rigopoulos, G., Psarras, J., \& Askounis, D. (2008). TAM model to evaluate user's attitude towards adoption of decision support systems. Journal of applied sciences, Vol.5, N.5, pp.899-902.

Robbins, S. (1994). Management. (4th Ed.). Prentice-Hall, Inc.

Rogers, E. (1995). Diffusion of Innovation. (4th Ed.). Free Press, New York.

Saeed, K., \& Helm, S. (2008). Examining the effects of information system characteristics \& perceived usefulness on post adoption usage of information systems. Information \& Management, Vol.11, pp.376-386. http://dx.doi.org/10.1016/j.im.2008.06.002

Saunders, C., \& Jones, J. (1992). Measuring Performance of the Information Systems Function. Journal of Management Information Systems, Vol.8, N.4, pp.63-73.

Sekaran, U. (2006). Research methods for business: A skill-building approach. (4th Ed.). John Wiley \& Sons, Inc, New Delhi.

Seyal, A., \& Rahman, M. (2003). A preliminary investigation of E-commerce adoption in small \& medium enterprises in Bruni. Journal of Global Information Technology Management, Vol.6, N.2, pp.6-26.

ShahM., \& Siddiqui F. (2006). Organizational critical success factors in adoption of e-banking at the Woolwich bank. The International Journal on Information Management, Vol.26, N.6, pp.442-456. http://dx.doi.org/10.1016/j.ijinfomgt.2006.08.003

Shaukat, M., \& Zafar, J. (2010). Impact of Sociological \& Organizational Factors on Information Technology Adoption: An Analysis of Selected Pakistani Companies. European Journal of Social Sciences, V.13, N.2, pp.305-320.

Shen, C., \& Chiou, J. (2010). The impact of perceived ease of use on Internet service adoption: The moderating effects of temporal distance \& perceived risk. Computers in Human Behavior, Vol.26, pp. 42-50. http://dx.doi.org/10.1016/j.chb.2009.07.003

Stair, R., \& Reynolds, G. (2010). Principles of Information Systems. (6th Ed.) Course technology, (25); Thomson place, Boston, USA.

Stegwee, R., \& Rukanova, B. (2003). Identification of Different Types of Standards for Domain-Specific Interoperability. Standard making: A Critical Research Frontier for Information Systems, Seattle, WA.

Tallon, P., Kraemer, K., \& Gurbaxani, V. (2000). Executives' Perceptions of the business value of information technology: A process-oriented approach. Journal of Management Information Systems, Vol.16, N.4, pp. 145-173.

Tang, M., \& Teo, T. (2000). Factors influencing the adoption of Internet banking. Journal of Association for Information System, Vol.1, No.15, pp.1-42.

Tang, S. (2000). An impact factor model of intranet adoption: an exploratory \& empirical research. The Journal of Systems \& Software, Vol.51, pp.157-173. http://dx.doi.org/10.1016/S0164-1212(99)00121-1

Turban, E., Aronson, J., Liang, T-P., \& Sharda, R. (2007). Decision Support \& Business Intelligence Systems. (8th Ed.). Upper Saddle River: Pearson Education.

Turban, E., Rainer, R., \& Potter, R. (2001). Introduction to information technology. John Wiley \& Sons, Inc.

Venkatesh, V., \& Morris, M. (2000). Why don't men ever stop to ask for directions? Gender, social influence, \& their role in technology acceptance \& usage behavior. MIS Quarterly, Vol.24, N.1, pp.115-139. http://dx.doi.org/10.2307/3250981

Vroom, V. (2002). Work \& motivation. New York: Wiley

Xianfeng, Q., Boxiong, L., \& Zhenwei, G. (2008). Conceptual Model of IT Infrastructure Capability \& Its Empirical Justification. Tsinghua Science \& Technology, Vol.13, N.5, pp.390-394. 
Yarbrough, A., \& Smith, T. (2007). Technology acceptance among physicians: a new take on TAM. Medical Care Research \& Review, pp.64-650.

Yin, R. (1994). Case study research: Design \& methods. (2th Ed.) Beverly Hills, CA: Sage Publishing.

Zikmund, W. (2003). Business Research Methods. Harcourt Brace Jovanovich: Fort Worth.

Table 1. Summary of Previous Studies

\begin{tabular}{|c|c|c|c|}
\hline Authors & Purpose & Data sources & Major results \\
\hline $\begin{array}{l}\text { Shaukat \& Zafar, } \\
\text { (2010) }\end{array}$ & $\begin{array}{l}\text { To identify the impact of } \\
\text { sociological } \& \\
\text { organizational factors on IT } \\
\text { adoption. }\end{array}$ & $\begin{array}{l}\text { The primary data was collected } \\
\text { through in-depth interviews \& field } \\
\text { surveys of } 48 \text { companies, } 24 \text { in } \\
\text { manufacturing sector ( } 12 \text { local \& } 12 \\
\text { foreign) \& } 24 \text { in banking sector }(12 \\
\text { local \& } 12 \text { foreign), in Pakistani } \\
\text { companies. }\end{array}$ & $\begin{array}{l}\text { Found that OS impacts the adoption } \\
\text { of IT. }\end{array}$ \\
\hline $\begin{array}{l}\text { Rezaei et al, } \\
(2009)\end{array}$ & $\begin{array}{l}\text { To investigate the influence } \\
\text { of organizational factors on } \\
\text { MIS success. }\end{array}$ & $\begin{array}{l}\text { Survey questionnaires were } \\
\text { gathered from } 132 \text { Extension } \\
\text { Managers from Iran's Agricultural } \\
\text { Extension Providers. }\end{array}$ & $\begin{array}{l}\text { Found that all the organizational } \\
\text { factors (department structure, IS } \\
\text { infrastructure \& MS) are } \\
\text { significantly correlated to the } \\
\text { success of IS. }\end{array}$ \\
\hline $\begin{array}{l}\text { Liu \& Chen, } \\
(2008)\end{array}$ & $\begin{array}{l}\text { To examine the effect of } \\
\text { individual differences, } \\
\text { tasks, \& decision models on } \\
\text { user acceptance of DSS. }\end{array}$ & $\begin{array}{l}\text { Experiment strategy applied on } 300 \\
\text { business students from mid-west } \\
\text { university. }\end{array}$ & $\begin{array}{l}\text { Found that individual differences } \\
\text { have effect on user acceptance of } \\
\text { DSS. }\end{array}$ \\
\hline Ngai et al, (2008) & $\begin{array}{l}\text { To examine the critical } \\
\text { success factors in the } \\
\text { adoption of Enterprise } \\
\text { resource planning. }\end{array}$ & $\begin{array}{l}\text { The review covers journals, } \\
\text { conference proceedings, doctoral } \\
\text { dissertation, \& textbooks from these } \\
10 \text { different countries \& regions in } \\
\text { China. }\end{array}$ & $\begin{array}{l}\text { Found that TMS is critical factor to } \\
\text { the successful implementation of } \\
\text { ERP systems. }\end{array}$ \\
\hline $\begin{array}{l}\text { Hussein et al, } \\
(2007)\end{array}$ & $\begin{array}{l}\text { To investigate the influence } \\
\text { of technological factors on } \\
\text { IS success. }\end{array}$ & $\begin{array}{l}\text { Using a survey method, data were } \\
\text { gathered from } 201 \text { users from four } \\
\text { electronic government (EG) } \\
\text { agencies in Malaysia. }\end{array}$ & $\begin{array}{l}\text { Found that IS integration has a } \\
\text { positive effect on IS success. }\end{array}$ \\
\hline $\begin{array}{l}\text { Lee \& Kim, } \\
(2007)\end{array}$ & $\begin{array}{l}\text { To examine the various } \\
\text { factors that affects the } \\
\text { implementation's success of } \\
\text { Internet-based information } \\
\text { systems. }\end{array}$ & $\begin{array}{l}\text { Structured questionnaire } 129 \text {, } \\
\text { Interviews } 9 \text { From among the } 2000 \\
\text { companies } 120 \text { companies selected } \\
\text { in Korean. }\end{array}$ & $\begin{array}{l}\text { Found that (TMS, IS infrastructure) } \\
\text { positively related to IS } \\
\text { implementation success. }\end{array}$ \\
\hline $\begin{array}{l}\text { Hussein et al, } \\
(2007)\end{array}$ & $\begin{array}{l}\text { To investigate the influence } \\
\text { of organizational factors on } \\
\text { IS success in selected public } \\
\text { sector agencies in Malaysia. }\end{array}$ & $\begin{array}{l}\text { Survey questionnaires were } \\
\text { gathered from } 201 \text { users from four } \\
\text { central agencies located at the } \\
\text { central administration complex in } \\
\text { Putrajaya. }\end{array}$ & $\begin{array}{l}\text { Found that all the organizational } \\
\text { factors (TMS, MS, } \\
\text { Decision-making structure) are } \\
\text { significantly } \\
\text { correlated to the success of IS } \\
\text { adoption. }\end{array}$ \\
\hline Ana et al, (2006) & $\begin{array}{l}\text { To explore organizational } \\
\text { factors affecting Internet } \\
\text { technology adoption. }\end{array}$ & $\begin{array}{l}\text { Questionnaire-based data from } 280 \\
\text { companies in Spain. }\end{array}$ & $\begin{array}{l}\text { Found that OS significantly } \\
\text { correlated to success internet } \\
\text { technology adoption. }\end{array}$ \\
\hline $\begin{array}{l}\text { Shah \& Siddiqui, } \\
\text { (2006) }\end{array}$ & $\begin{array}{l}\text { To investigate } \\
\text { organizational critical } \\
\text { success factors in e-banking } \\
\text { adoption at The } \\
\text { Woolwich bank. }\end{array}$ & $\begin{array}{l}\text { Data was collected using interviews, } \\
\text { observations \& referring to } \\
\text { historical documents (data } \\
\text { triangulation) of the Woolwich bank } \\
\text { in United Kingdom. }\end{array}$ & $\begin{array}{l}\text { Found that the organizational } \\
\text { factors would be most critical for } \\
\text { success in e-banking adoption. }\end{array}$ \\
\hline $\begin{array}{l}\text { Hwang et al, } \\
\text { (2004) }\end{array}$ & $\begin{array}{l}\text { To identify critical factors } \\
\text { influencing the adoption of } \\
\text { data warehouse technology. }\end{array}$ & $\begin{array}{l}\text { The questionnaires used in this study } \\
\text { are to collect appropriate data in } \\
\text { Taiwanese banks. A total of } 50 \\
\text { questionnaires in the banking } \\
\text { industry in Taiwan. }\end{array}$ & $\begin{array}{l}\text { Found TMS is an important factor } \\
\text { affecting the adoption of data } \\
\text { warehouse technology. }\end{array}$ \\
\hline $\begin{array}{l}\text { Nathan et al, } \\
\text { (2004) }\end{array}$ & $\begin{array}{l}\text { To study the relationship } \\
\text { between top management } \\
\text { support, the IS function \& } \\
\text { performance. }\end{array}$ & $\begin{array}{l}\text { Survey questionnaires were mailed } \\
\text { to } 800 \text { IS executives of } \\
\text { organizations in the US. }\end{array}$ & $\begin{array}{l}\text { Found that TMS has a significant in } \\
\text { influencing the effectiveness of the } \\
\text { IS function in an organization. }\end{array}$ \\
\hline
\end{tabular}




\begin{tabular}{|c|c|c|c|}
\hline $\begin{array}{l}\text { Grandon \& } \\
\text { Pearson, } \\
(2004)\end{array}$ & $\begin{array}{l}\text { To Examine the determinant } \\
\text { factors of strategic value \& } \\
\text { adoption of electronic } \\
\text { commerce as perceived by } \\
\text { top managers in small \& } \\
\text { medium sized enterprises } \\
\text { (SME) in the Midwest } \\
\text { region of the US. }\end{array}$ & $\begin{array}{l}\text { They collected data from top } \\
\text { managers or owners of SME by } \\
\text { using an Internet survey (100) in US. }\end{array}$ & $\begin{array}{l}\text { Found that PEOU, \& PU have } \\
\text { significant positive relationship } \\
\text { with successful of electronic } \\
\text { commerce adoption. }\end{array}$ \\
\hline $\begin{array}{l}\text { Bradford \& Florin, } \\
\text { (2003) }\end{array}$ & $\begin{array}{l}\text { To examine the success } \\
\text { factors of ERP systems by } \\
\text { develop a model that draws } \\
\text { upon Diffusion of } \\
\text { Innovation (DOI) theory \& } \\
\text { IS implementation } \\
\text { literature. }\end{array}$ & $\begin{array}{l}\text { A survey was administered to } \\
\text { randomly select members of } \\
\text { America's SAP User Group. }\end{array}$ & $\begin{array}{l}\text { Found TMS positively related ERP } \\
\text { implementation success. }\end{array}$ \\
\hline $\begin{array}{l}\text { Bajwa \& Ross, } \\
(2002)\end{array}$ & $\begin{array}{l}\text { To identify the factors } \\
\text { influencing the adoption } \& \\
\text { implementation of } \\
\text { organizational intranets. }\end{array}$ & $\begin{array}{l}\text { Used case study that is based on } \\
\text { observations of an intranet } \\
\text { development project within the } \\
\text { business school of a university in the } \\
\text { northwest. }\end{array}$ & \\
\hline
\end{tabular}

Table 2. Test of Construct Validity

\begin{tabular}{|c|c|c|c|}
\hline Correlation of item-to-total & Sig. (2-tailed) & Item & Factor \\
\hline $0.801 * *$ & .000 & PEOU 1 & PEOU \\
\hline $0.821 * *$ & .000 & PEOU 2 & \\
\hline $0.754 * *$ & .000 & PEOU 3 & \\
\hline $0.691 * *$ & .000 & PEOU 4 & \\
\hline $0.802 * *$ & .000 & PU 1 & PU \\
\hline $0.806 * *$ & .000 & PU 2 & \\
\hline $0.803 * *$ & .000 & PU 3 & \\
\hline $0.802 * *$ & .000 & PU 4 & \\
\hline $0.736^{* *}$ & .000 & PU 5 & \\
\hline $0.843 * *$ & .000 & IT infrastructure 1 & IT infrastructure \\
\hline $0.790 * *$ & .000 & IT infrastructure 2 & \\
\hline $0.753 * *$ & .000 & IT infrastructure 3 & \\
\hline $0.795^{* *}$ & .000 & IT infrastructure 4 & \\
\hline $0.737 * *$ & .000 & IT infrastructure 5 & \\
\hline $0.699 * *$ & .000 & IS interoperability 1 & IS interoperability \\
\hline $0.748 * *$ & .000 & IS interoperability 2 & \\
\hline $0.708 * *$ & .000 & IS interoperability 3 & \\
\hline $0.639 * *$ & .000 & IS interoperability 4 & \\
\hline $0.873 * *$ & .000 & TMS 1 & TMS \\
\hline $0.918 * *$ & .000 & TMS 2 & \\
\hline $0.915 * *$ & .000 & TMS 3 & \\
\hline $0.804 * *$ & .000 & MS 1 & MS \\
\hline $0.848 * *$ & .000 & MS 2 & \\
\hline $0.823 * *$ & .000 & MS 3 & \\
\hline $0.819 * *$ & .000 & MS 4 & \\
\hline $0.562 * *$ & .000 & MS 5 & \\
\hline $0.827 * *$ & .000 & OS 1 & OS \\
\hline $0.672 * *$ & .000 & OS 2 & \\
\hline $0.747 * *$ & .000 & OS 3 & \\
\hline $0.577 * *$ & .000 & OS 4 & \\
\hline $0.571 * *$ & .000 & DSS adopt 1 & Successful Adoption of DSS \\
\hline $0.592 * *$ & .000 & DSS adopt 2 & \\
\hline $0.685 * *$ & .000 & DSS adopt 3 & \\
\hline $0.675 * *$ & .000 & DSS adopt 4 & \\
\hline $0.633 * *$ & .000 & DSS adopt 5 & \\
\hline $0.644 * *$ & .000 & DSS adopt 6 & \\
\hline $0.654 * *$ & .000 & DSS adopt 7 & \\
\hline
\end{tabular}

** Correlation is significant at the 0.01 level (2-tailed). 
Table 3. Cronbach's Alpha for the Scales

\begin{tabular}{|c|c|}
\hline $\begin{array}{c}\text { Cronbach's } \\
\text { Alpha }\end{array}$ & Variables \\
\hline .77 & PEOU \\
.85 & PU \\
.84 & IT infrastructure \\
.64 & IS interoperability \\
.89 & TMS \\
.83 & MS \\
.67 & OS \\
.71 & Successful adoption of DSS \\
\hline
\end{tabular}

Table 4. The Multicollinearity Test

\begin{tabular}{|c|c|c|}
\hline VIF & Tolerance & Variables \\
\hline 1.109 & .901 & PEOU \\
1.271 & .787 & PU \\
1.427 & .701 & IT infrastructure \\
1.508 & .663 & IS interoperability \\
1.723 & .580 & TMS \\
2.063 & .485 & MS \\
1.787 & .560 & OS \\
\hline
\end{tabular}

Table 5. Skewness Coefficients

\begin{tabular}{|c|c|}
\hline Skewness & Variable \\
\hline-.122 & PEOU \\
-.423 & PU \\
-1.353 & IT infrastructure \\
-.530 & IS interoperability \\
-.689 & TMS \\
-.319 & MS \\
-.264 & OS \\
-.256 & Successful adoption of DSS \\
\hline
\end{tabular}

Table 6. Fitness of the Model for Regression Analysis

Model Summary ${ }^{\text {b }}$

\begin{tabular}{|c|c|c|c|c|c|c|c|}
\hline Sig. & F & $\begin{array}{c}\text { Durbin- } \\
\text { Watson }\end{array}$ & $\begin{array}{c}\text { S.D Error of the } \\
\text { Estimate }\end{array}$ & $\begin{array}{c}\text { Adjusted } \\
\text { R Square }\end{array}$ & $\begin{array}{c}\mathbf{R} \\
\text { Square }\end{array}$ & R & Mode \\
\hline .000 & 11.877 & 2.037 & .35148 & .322 & .352 & $.593^{\mathrm{a}}$ & 1 \\
\hline
\end{tabular}

a. Predictors: (Constant), OS, IT infrastructure, PEOU, PU, TMS, IS interoperability, MS.

b. Dependent Variable: successful adoption of DSS.

* Statistically significant at the level of significance $(\alpha \leq 0.05)$ 
Table 7. T-Value \& Significance Level $(\alpha)$

\section{Coefficients}

\begin{tabular}{|c|c|c|c|c|c|}
\hline \multirow{2}{*}{ Sig } & \multirow{2}{*}{$\mathbf{t}$} & $\begin{array}{c}\text { Standardized } \\
\text { Coefficients }\end{array}$ & \multicolumn{2}{|c|}{$\begin{array}{c}\text { Unstandardized } \\
\text { Coefficients }\end{array}$} & \multirow{2}{*}{ Model } \\
\cline { 2 - 5 } & & Beta & S.D Error & B & (Constant) \\
\hline .000 & 6.011 & & .308 & 1.854 & PEOU \\
.296 & 1.049 & .072 & .039 & .041 & PU \\
.000 & 3.709 & .272 & .060 & .224 & .300 \\
.000 & 5.039 & .392 & .060 & IT infrastructure \\
.886 & .143 & .011 & .069 & .010 & IS interoperability \\
.682 & -.411 & -.035 & .040 & -.016 & TMS \\
.983 & -.022 & -.002 & .051 & -.001 & MS \\
.376 & .889 & .077 & .047 & .042 & OS \\
\hline
\end{tabular}

a. Dependent Variable: Successful adoption of DSS

Statistically significant at the level of significance $(\alpha \leq 0.05)$

Table 8. Level of Significance of the User Gender \& the Adoption of DSS

\begin{tabular}{|c|c|c|c|c|l|c|}
\hline \multicolumn{2}{|c|}{ t-test for equality of Means } & \multicolumn{2}{|c|}{$\begin{array}{c}\text { Levene's Test for } \\
\text { Equality of Variance }\end{array}$} & \\
\hline Sig (2-tailed) & df & T & Sig & F & \\
\hline .409 & 159 & -.827 & .156 & 2.035 & $\begin{array}{l}\text { Equal variance } \\
\text { assumed } \\
\text { Equal variance not } \\
\text { assumed }\end{array}$ & $\begin{array}{c}\text { Adoption of } \\
\text { DSS }\end{array}$ \\
.372 & 32.185 & -.905 & & & & \\
\hline
\end{tabular}

Statistically significant at the level of significance $(\alpha \leq 0.05)$

Table 9. Level of Significance of the Age, Education Level, Commission, Job Description, \& Experience toward the Adoption of DSS

\begin{tabular}{|c|c|c|c|c|c|c|}
\hline Sig. & $\mathbf{F}$ & $\begin{array}{c}\text { Mean } \\
\text { Square }\end{array}$ & df & $\begin{array}{c}\text { Sum of } \\
\text { Squares }\end{array}$ & & $\begin{array}{l}\text { Demographic } \\
\text { Characteristics }\end{array}$ \\
\hline .089 & 1.631 & $\begin{array}{l}1.057 \\
.648\end{array}$ & $\begin{array}{c}12 \\
148 \\
160\end{array}$ & $\begin{array}{c}12.680 \\
95.879 \\
108.559\end{array}$ & $\begin{array}{c}\text { Between Groups } \\
\text { Within Groups } \\
\text { Total }\end{array}$ & Age \\
\hline .878 & .551 & $\begin{array}{l}.199 \\
.361\end{array}$ & $\begin{array}{c}12 \\
148 \\
\mathbf{1 6 0}\end{array}$ & $\begin{array}{c}2.385 \\
53.416 \\
\mathbf{5 5 . 8 0 1}\end{array}$ & $\begin{array}{c}\text { Between Groups } \\
\text { Within Groups } \\
\text { Total }\end{array}$ & Education level \\
\hline .260 & 1.241 & $\begin{array}{l}3.171 \\
2.554\end{array}$ & $\begin{array}{c}12 \\
148 \\
160\end{array}$ & $\begin{array}{c}38.051 \\
378.036 \\
\mathbf{4 1 6 . 0 8 7}\end{array}$ & $\begin{array}{c}\text { Between Groups } \\
\text { Within Groups } \\
\text { Total }\end{array}$ & Commission \\
\hline .696 & .754 & $\begin{array}{l}.594 \\
.787\end{array}$ & $\begin{array}{c}12 \\
148 \\
\mathbf{1 6 0}\end{array}$ & $\begin{array}{c}7.123 \\
116.516 \\
\mathbf{1 2 3 . 6 4 0}\end{array}$ & $\begin{array}{c}\text { Between Groups } \\
\text { Within Groups } \\
\text { Total }\end{array}$ & Job description \\
\hline .158 & 1.431 & $\begin{array}{l}1.368 \\
.956\end{array}$ & $\begin{array}{c}12 \\
148 \\
160\end{array}$ & $\begin{array}{c}16.419 \\
141.531 \\
\mathbf{1 5 7 . 9 5 0}\end{array}$ & $\begin{array}{l}\text { Between Groups } \\
\text { Within Groups } \\
\text { Total }\end{array}$ & Experience \\
\hline
\end{tabular}

Statistically significant at the level of significance $(\alpha \leq 0.05)$ 


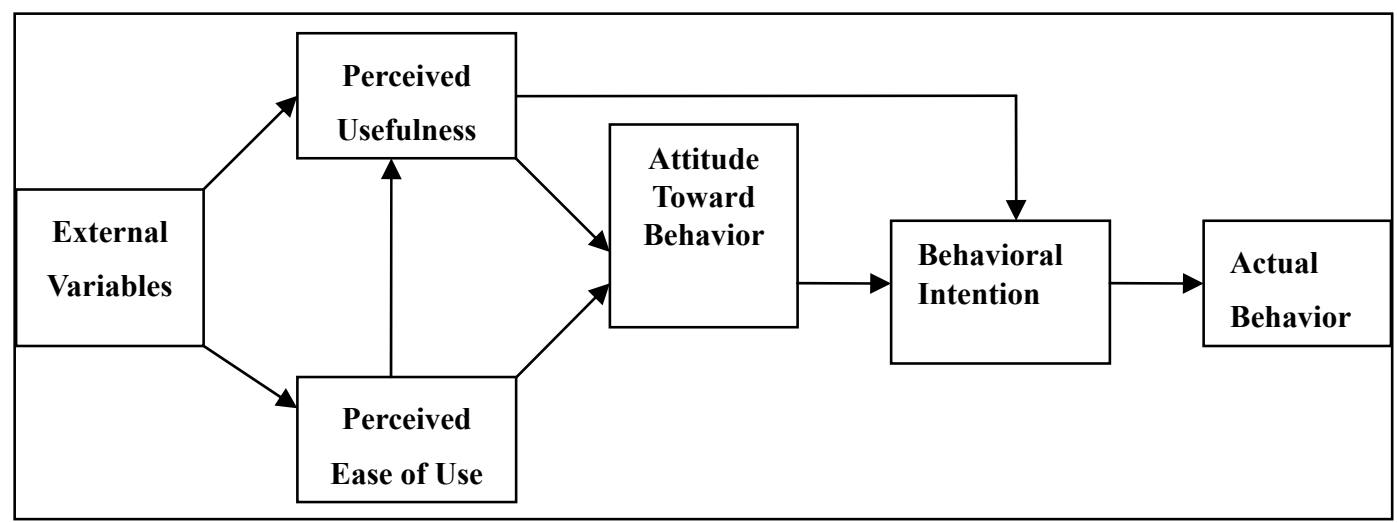

Figure 1. Technology Acceptance Model

Source: (Davis, 1993)

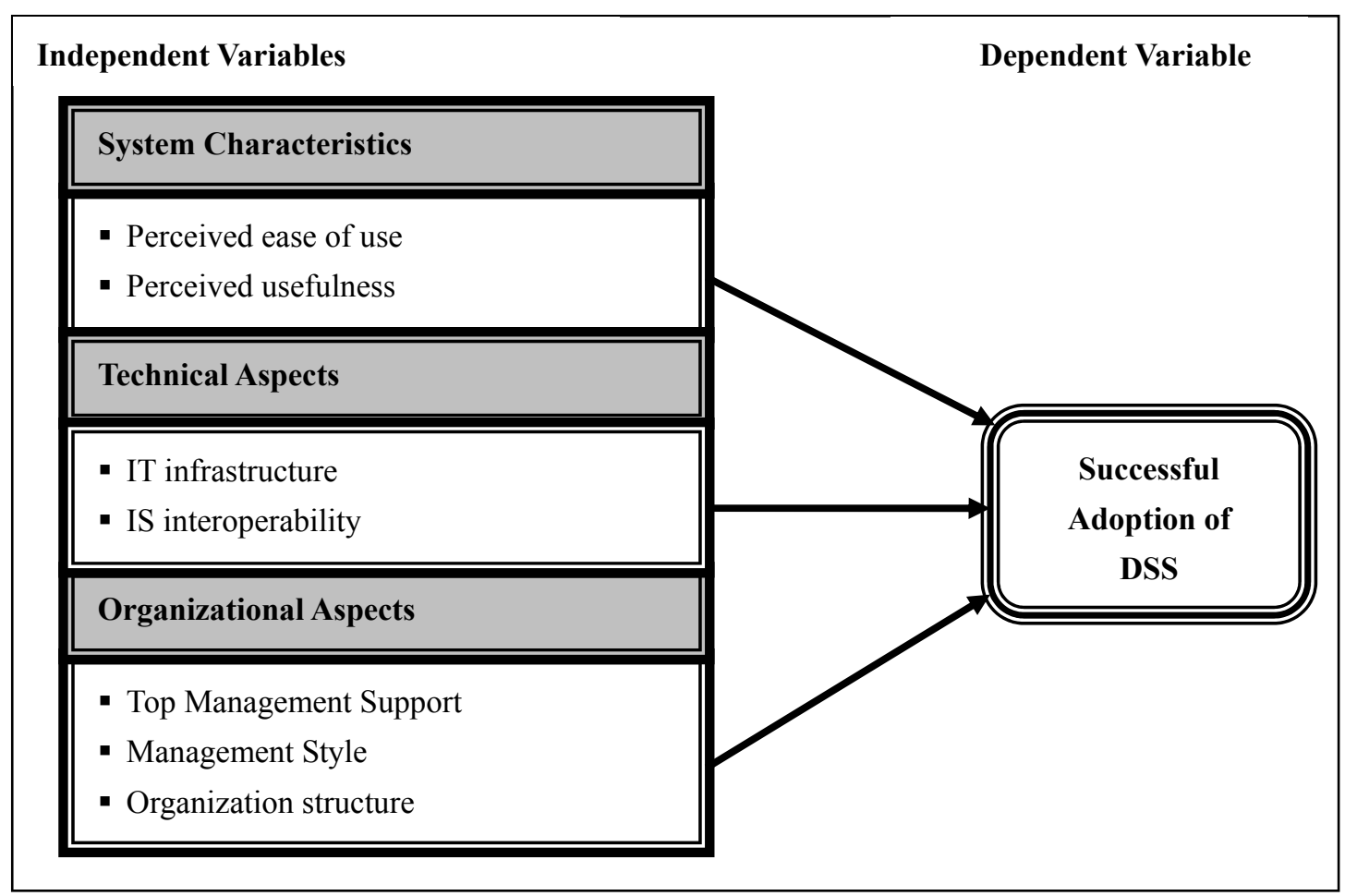

Figure 2. The Proposed Model of the Research 